\title{
A study of the effect of legal settlement on post-concussion symptoms
}

\author{
C. R. A. FEE $^{1} \&$ W. H. RUTHERFORD ${ }^{2}$ \\ ${ }^{2}$ Royal Victoria Hospital, Belfast, Northern Ireland
}

${ }^{1}$ Departments of Accident and Emergency Medicine, The Ulster Hospital, Dundonald, anळ

\section{SUMMARY}

Forty-four consecutive patients with concussion for whom a medico-legal report had̆ been written were followed up for 3-4 years after their accidents. Three cases were stilt pending at the end of the study. Fifty-seven per cent complained of symptoms when the medico-legal reports were written (mean interval from accident 12.9 months), $39 \%$ had symptoms at the time of settlement (mean interval 22.1 months) and $34 \%$ had symptoms one year later.

When these results were compared with a general series from the same department some years earlier, it was found that the symptoms at the time of writing the repott were not significantly different from symptoms at 6 weeks in the earlier series, but the symptoms one year after settlement were almost two-and-a-half times greater than th\& symptoms at 12 months in the general series. No evidence could be found to suggest an $\vec{\varnothing}$ organic basis for the higher symptom rate in the litigation series. It is suggested that the litigation process itself is a factor in the persistence of symptoms and this effegf continues after legal settlement has been reached. Early settlement of the cases mighid significantly reduce morbidity.

\section{INTRODUCTION}

In two previous studies of patients with concussion (Rutherford et al., 1977, 1978), the authors suggested that there was good evidence that late symptoms were influenced bof both organic and psychological factors. This work was based on an unselecteds consecutive series of patients arriving at an accident and emergency department.

In recent years, requests to the Royal Victoria Hospital in Belfast, Northern Irelanç for medico-legal reports on these patients have been forwarded to one of the authots

Correspondence: $\mathrm{Mr}$ C. R. A. Fee, Consultant in the Accident and Emergency Department, Craigavon Areळ Hospital, Craigavon BT63 5QQ, Co. Armagh, Northern Ireland 
(WHR). A consecutive series of these patients was studied to establish symptom rates up to one year after settlement and to compare these with the late symptom rates in the earlier series.

\section{PATIENTS AND METHODS}

From 1981 to 1983,46 patients who had been admitted overnight to the admission ward of the Royal Victoria Hospital, Belfast, with a diagnosis of concussion, were later referred by solicitors to one of the authors (WHR) for a medico-legal report. It is the policy in this hospital that closed head injury followed by amnesia is an indication for admission. Those not requiring neurosurgical care and without any serious accompanying injury are admitted under the care of the accident and emergency department. The same author saw most of the admission cases on the following morning and, at follow up clinic, 6 weeks later. The duration of post-traumatic amnesia was assessed in all cases. This was usually done on the morning after admission, but, in some cases, at a later attendance. The time at which 999 emergency phone calls were made to the ambulance department was used to verify the time of the accident. The times of arrival at the hospital and of admission to the ward (both routinely recorded by the medical records staff) were used to establish the time at which the memory became clear and continuous, this being taken as the end point of amnesia.

When the medico-legal reports were being prepared, patients were instructed both in the importance of reporting all symptoms and avoiding exaggeration. Patients were then left to make their statements without any further prompting.

The late follow-up was conducted 2-4 years after the time of the accident. Questionnaires were sent to all patients seeking information about the time of first contact with the solicitor, the time of settlement and the presence or absence of symptoms at the time of settlement. Twenty patients replied but, in two cases, the information was inadequate and these cases were discarded. The remaining 26 cases were contacted personally by one author (CRAF) and the questionnaire completed at that visit. This proved a difficult and tedious process.

\section{RESULTS}

After the withdrawal of two cases where documentation was unsatisfactory, 44 patients remained. These formed the basis of the legislation series in this study. The general series comprised 145 patients admitted with minor head injuries to the observation ward of the same hospital and reported previously (Rutherford et al., 1977, 1978).

Twenty-two patients in the litigation series were involved in road traffic accidents, 18 in assaults and four in industrial accidents. At the time of the medico-legal report, 21 patients complained of headache, seven of anxiety, five of irritability, five of dizziness, two of depression, two of insomnia and two of difficulty with their memory.

Table 1 compares the litigation series and the general series in terms of age, sex, post- 
Table 1 Distribution of post-traumatic amnesia, age and sex in litigation series and general series*

\begin{tabular}{|c|c|c|c|c|}
\hline & & $\begin{array}{c}\text { Litigation } \\
\text { Series }\end{array}$ & $\begin{array}{c}\text { General } \\
\text { Series }\end{array}$ & $\begin{array}{c}\mathrm{X}^{2} \text { and } \\
P \text { values }\end{array}$ \\
\hline Post-traumatic amnesia & $\begin{array}{r}15 \mathrm{~min} \\
15-59 \mathrm{~min} \\
60 \mathrm{~min}\end{array}$ & $\begin{array}{l}21(49 \%) \\
11(26 \%) \\
11(26 \%)\end{array}$ & $\begin{array}{l}41(31 \%) \\
46(35 \%) \\
44(34 \%)\end{array}$ & $\begin{array}{l}\mathrm{X}^{2}=4 \cdot 350 \\
\text { df } 2 \\
0 \cdot 2>P>0.1\end{array}$ \\
\hline & $<20$ years & $4(9 \cdot 3 \%)$ & $43(33 \%)$ & $X^{2}=9 \cdot 198$ \\
\hline Age & $\begin{array}{r}20-40 \text { years } \\
40 \text { years }\end{array}$ & $\begin{array}{l}22(51 \%) \\
17(40 \%)\end{array}$ & $\begin{array}{l}47(36 \%) \\
41(31 \%)\end{array}$ & $\begin{array}{l}\text { df } 2 \\
0.02>P>0.01\end{array}$ \\
\hline Headaches at $24 \mathrm{~h}$ & $\begin{array}{l}\text { Yes } \\
\text { No11 }\end{array}$ & $\begin{array}{l}24(69 \%) \\
(31 \%)\end{array}$ & $\begin{array}{r}108(74 \%) \\
37(26 \%)\end{array}$ & $\begin{array}{l}X^{2}=0.247 \\
\text { df } 1 \\
0.7>P>0.6\end{array}$ \\
\hline Positive CNS signs at $24 \mathrm{~h}$ & $\begin{array}{l}\text { Yes } \\
\text { No }\end{array}$ & $\begin{array}{r}5(14 \%) \\
30(86 \%)\end{array}$ & $\begin{array}{l}40(29 \%) \\
99(71 \%)\end{array}$ & $\begin{array}{l}X^{2}=2 \cdot 353 \\
\text { df } 1 \\
0 \cdot 2>P>0.1\end{array}$ \\
\hline Head injury caused by falls & $\begin{array}{l}\text { Yes } \\
\text { No }\end{array}$ & $\begin{array}{c}3(6 \cdot 8 \%) \\
41(93 \cdot 2 \%)\end{array}$ & $\begin{array}{r}33(22 \cdot 8 \%) \\
112(77 \cdot 2 \%)\end{array}$ & $\begin{array}{l}X^{2}=4.58 \\
\text { df } 1 \\
0.05>P>0.02\end{array}$ \\
\hline Sex & $\begin{array}{r}\mathbf{M} \\
\mathbf{F}\end{array}$ & $\begin{array}{l}33(75 \%) \\
11(25 \%)\end{array}$ & $\begin{array}{l}83(63 \%) \\
48(37 \%)\end{array}$ & $\begin{array}{l}X^{2}=4.58 \\
\text { df } 1 \\
0.05>P>0.02\end{array}$ \\
\hline
\end{tabular}

*In the litigation series, PTA unknown in one case, age unknown in one case, and headaches and CNS signs unknown in nine cases. In the general series, CNS signs unknown in six cases.

traumatic amnesia, headaches at $24 \mathrm{~h}$, abnormal CNS signs at $24 \mathrm{~h}$ and the number of patients whose accidents were caused by falls.

In respect of age, there were significantly fewer patients below 20 years of age in the litigation group, but no significant difference above this age $\left(X^{2}=0.65\right.$, df $1, \underline{3}$. $0.5>P>0.3$ ). As regards sex, post-traumatic amnesia, headaches at $24 \mathrm{~h}$ and abnormal CNS signs at $24 \mathrm{~h}$, there were no significant differences. The percentage of falls was significantly smaller in the litigation series (information was missing for headaches and CNS signs in nine litigation patients, and for CNS signs in six of the general series).

Thirty-six litigation patients $(82 \%)$ had made contact with their solicitor within $2 \frac{}{D}$

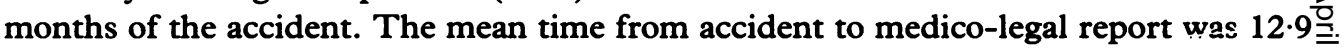
months, with a range of 2-98 months. The mean time from accident to settlement was $22 \cdot 1$ months, with a range of 6-50 months. This includes three cases which were abandoned without any settlement, but excludes three cases still pending at the time of $\tilde{\omega}_{\tilde{N}}$ writing 3 years after their accidents.

Table 2 shows the symptom rates in the litigation series at the time of writing theo report, at the time of settlement and one year after the settlement. For comparison, it shows that the symptom rates had fallen to $39 \%$, but one year after settlement to only $34 \%$. 
Table 2 Symptom rates in litigation series and in general series*

\begin{tabular}{|c|c|c|c|c|c|}
\hline & \multicolumn{2}{|c|}{ Litigation series } & \multicolumn{2}{|c|}{ General series } & \multirow{2}{*}{$\begin{array}{l}X^{2} \text { and } \\
P \text { values }\end{array}$} \\
\hline & Symptoms & No symptoms & Symptoms & No symptoms & \\
\hline $\begin{array}{l}\text { Litigation series at report, } \\
\text { mean } 12.9 \text { months } \\
\text { General series } \\
\text { at } 6 \text { weeks }\end{array}$ & $\begin{array}{c}25 \\
(57 \%)\end{array}$ & $\begin{array}{c}19 \\
(43 \%)\end{array}$ & $\begin{array}{c}74 \\
(51 \%)\end{array}$ & $\begin{array}{c}71 \\
(49 \%)\end{array}$ & $\begin{array}{l}X^{2}=0.251 \\
\text { df } 1 \\
0.7>P>0.08\end{array}$ \\
\hline $\begin{array}{l}\text { Litigation series at } \\
\text { settlement, mean } \\
22 \cdot 1 \text { months }\end{array}$ & $\begin{array}{c}16 \\
(39 \%)\end{array}$ & $\begin{array}{c}- \\
25 \\
(61 \%)\end{array}$ & & & \\
\hline $\begin{array}{l}\text { Litigation series one year } \\
\text { after settlement } \\
\text { General series at one year }\end{array}$ & $\begin{array}{c}14 \\
(34 \%)\end{array}$ & $\begin{array}{c}27 \\
(66 \%)\end{array}$ & $\begin{array}{c}19 \\
(14.5 \%)\end{array}$ & $\begin{array}{c}112 \\
(85 \cdot 5 \%)\end{array}$ & $\begin{array}{l}X^{2}=7 \cdot 17 \\
\text { df } 1 \\
0.01>P>0.001\end{array}$ \\
\hline
\end{tabular}

*Excludes three cases still pending at time of writing.

The symptom rate at the time of report in the litigation series was not significantly different from the rate of 6 weeks in the general series. The symptom rate one year after settlement was 2.3 times higher than the symptom rate one year after accident in the general series, and this difference is significant.

Table 3 divides the patients in the litigation series into those settled within 18 months and those settled in over 18 months, and shows the symptom rates at one year after settlement. The symptom rates among the cases settled early and later are not significantly different.

\section{DISCUSSION}

This study set out to assess the effect of being involved in litigation upon the late symptom rates in patients with concussion. It is sometimes assumed that every person who engages in a law suit automatically becomes a malingerer and will admit to no improvement until litigation has been settled. The first clear result of this study is that, by the time of writing the medico-legal reports (at a mean interval of 12.9 months), $43 \%$ of patients were already symptom free. In the ensuing $\mathbf{9 \cdot 2}$ months (on average) until settlement, a further $18 \%$ became symptom free. However, in the year after settlement, there was only a small further improvement involving $5 \%$ of patients.

This is a very different picture from that reported by Miller in his classic article in 1961. However, his series of 50 patients, where 45 made a complete recovery within 2 
Table 3 Symptom rates at one year after settlement by early or late settlement*

\begin{tabular}{lcc}
\hline & $\begin{array}{c}\text { Symptoms one year after } \\
\text { settlement }\end{array}$ & $\begin{array}{c}\text { No symptoms } \\
\text { one year after settlement }\end{array}$ \\
\hline Settled in less than 18 months & 5 & 11 \\
Settled in over 18 months & $(31 \%)$ & $(69 \%)$ \\
& 9 & 16 \\
& $(36 \%)$ & $(64 \%)$ \\
\hline
\end{tabular}

*Table excludes three cases, litigation still pending.

years of settlement, contained patients diagnosed by Miller as suffering from 'accident neurosis' and he may have deliberately selected flagrant examples of the condition. 3 通. Some, but not all of them, had head injuries.

In comparing the late results of the two series, it can be seen that there is littledifference between the symptom rates at 6 weeks in the general series $(51 \%)$ and at $a \vec{N}$ mean of 12.9 months (the time of writing the report) in the litigation series $(57 \%)$. It is unfortunate that the authors do not have the symptom rate for sufficient numbers of the $\vec{z}$ litigation patients at 6 weeks to make a direct comparison at that interval. However, the

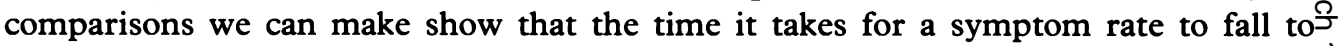
approximately $50 \%$ is much longer in the litigation series than in the general series.

Symptom rates at one year for the general series were $14.5 \%$ compared with $57 \%$ apa mean 12.9 months in the litigation series. There is still a significant difference when ore compares this one-year rate in the general series $(14.5 \%)$ with the rate one year aftor litigation is settled (34\%). This may be a more comparable stage in the more slowlyo evolving picture following litigation.

The difference between the two series can be explained in two ways. Patients with a $\stackrel{\varrho}{\rightarrow}$ bad prognosis are more prone to take legal action, or patients equivalent in severity and 3 prognosis make legal claims because they stand to gain financially, but the experience of going through the process of litigation had a deleterious effect on the late symptom rate.:

From the authors earlier studies, certain early factors which were associated with $\frac{\Phi}{3}$ high symptom rates were identified. These included being a woman, sustaining one's: accident from a fall, complaining of a headache on the morning after the accident or having abnormal CNS signs. There was no significant difference between the two seriesô except in the case of falls which were significantly less in the litigation series.

In this series, patients did not wait for a year or two to see whether their symptoms? would settle and then make a claim if they persisted. They almost all contacted theiro solicitors in the early weeks following their accidents.

There are not many prospective studies of symptoms following head injuries, and $N$ there is a considerable variation in the incidence of such symptoms in the different 0 series. In an earlier study (Rutherford et al., 1977), the authors found $51 \%$ of patients $\omega$ with symptoms at 6 weeks. Rimel et al. (1981) gave a figure of $84 \%$ at 3 months, compared with $60 \%$ by Wrightson \& Grenwall (1980). By one year after injury, the rate in a previous study (Rutherford et al., 1978) was 14.5\%. Amphoux et al. (1977), in as study of symptoms among construction workers in France (not a prospective study), found an incidence of $49 \%$ at 1-2 years. 
Tarsh \& Royston (1985) have shown that, in accident neurosis, the attitude of the family may have a marked influence on the outcome. Often the family becomes overprotective towards the patient. Looking after the patient may become the dominant theme of family life. While outsiders may tend to be sceptical about the patient's symptoms, the family has total belief. If the patient had been a dominant personality, roles may be reversed and a spouse take over the dominant role. Once these family attitudes are well established, they are very difficult to reverse.

The authors have not attempted to quantify the number of malingerers. Their impression is that they form a very small percentage of the total. Trimble (1981) traced the argument between physical and psychological factors in post-traumatic neurosis from the eighteenth century up to the present day. There is nothing in this study to refute his conclusion that the condition results from an interplay of both organic and psychological factors.

If the high late-symptom rate in the litigation series is due to continuing emotional stress, then one might have expected those whose cases were settled earlier to have had lower symptom rates and those with prolonged litigation higher. The authors made this comparison and found no significant difference. There may be a critical period from accident to settlement beyond which the effects of associated emotional stress becomes relatively fixed. If so, the present interval of $12-18$ months is too long.

\section{ACKNOWLEDGEMENTS}

The authors are very grateful to Dr J. D. Merrett and Mr J. McGirk from the Department of Medical Computing and Statistics, The Queen's University, Belfast, for help with the statistical tests, to Mrs Marie Loughran for typing the manuscript and to Mrs Cheryl Milligan for help in tracing the medico-legal cases.

\section{REFERENCES}

Amphoux M., Gagey P. M., Le Flem A. \& Pavy F. 1977 Le devenir du syndrome post-commotonnel. Revue de Medecine du Travail 122, 53-75.

Miller H. (1961) Accident neurosis. British Medical fournal i, 991-8.

Rimel R. W., Giordani B., Barth J. T., Bell T. J. \& Jane J. A. (1981) Disability caused by minor head injury. Neurosurgery 9, 221-8.

Rutherford W. H., Merrett J. D. \& McDonald J. R. (1977) Sequelae of concussion caused by minor head injuries. Lancet i, 1-4.

Rutherford W. H., Merrett J. D. \& McDonald J. R. (1978) Symptoms at one year following concussion from minor head injuries. Injury 10, 225-30.

Tarsh M. J. \& Royston C. (1985) A follow-up study of accident neurosis. British fournal of Psychology 146, 18-25.

Trimble M. R., (1981) Post-Traumatic Neurosis. Chichester, John Wiley.

Wrightson P. \& Grenwall D. (1980) Time off work and symptoms after minor head injury. Injury 12, 445-54. 